\title{
Rounding Harmony in Mfantse: Evidence and Differences
}

Patience Obeng ${ }^{1 *}$ and Yvonne A.A. Ollennu ${ }^{2}$

${ }^{1}$ Department of Akan-Nzema Education, University of Education, Winneba, Ghana

${ }^{2}$ Department of Ga-Dangme Education, University of Education, Winneba, Ghana

Corresponding Author: Patience Obeng, E-mail: patience70obeng@gmail.com

\begin{tabular}{|c|c|}
\hline ARTICLE INFO & ABSTRACT \\
\hline $\begin{array}{l}\text { Received: August 15, } 2020 \\
\text { Accepted: September } 25,2020 \\
\text { Volume:3 } \\
\text { Issue: } 9 \\
\text { DOI: } 10.32996 / \text { ijllt.2020.3.9.14 }\end{array}$ & $\begin{array}{l}\text { This paper investigated rounding harmony in two subdialects of Mfantse spoken in } \\
\text { the Central Region of Ghana. Borbor and Edwumako dialects are part of the Akan } \\
\text { language and belongs to Kwa on the Niger-Congo branch of languages. Data was } \\
\text { from the Mfantseman and Edwumako districts from } 45 \text { participants aged } 20 \text { years } \\
\text { and above. The Autosegmental framework was used for data analysis. We looked } \\
\text { first at the sounds and brought out the differences between Borbor sounds and that }\end{array}$ \\
\hline $\begin{array}{l}\text { Mfantse, labialization, rounding } \\
\text { harmony, phonemic, assimilation, } \\
\text { vowel, diacritic, subdialect }\end{array}$ & $\begin{array}{l}\text { of Edwumako. The study established that Mfantse is not the same in all its } \\
\text { phonological presentations in all its subdialects. In terms of sound distribution, the } \\
\text { central unadvanced vowel is strictly word final in Borbor while it is both word initial } \\
\text { and final in Edwumako. Some aspects of rounding harmony occur in both Borbor } \\
\text { and Edwumako while other aspects occur in Borbor and partially in Edwumako. } \\
\text { Other aspects are present in Edwumako only. }\end{array}$ \\
\hline
\end{tabular}

\section{Introduction}

There is no dispute that feature harmony exists in some languages. Authors such as Akanlig-Pare and Krobea-Asante (2012), Besides the ATR harmony another harmony that is well established in Mfantse is the labialized or rounding harmony (henceforth RH). Several phonologists such as Dolphyne (1988), Obeng (1999), Abaka (2003, 2012) and Bota (2002) have confirmed vowel harmony in Akan. Several studies have also confirmed different harmony types in other languages. AkanligPare (1994) on Buli, Hansson (2010) on some group of languages, Morton (2012) on Anii, Casali (2003, 2008, 2016), Moller (2016), on Bale and Rose (2016) also on a large-scale study on some African languages, Likewise, labialization or rounding harmony has also been established. Dolphyne $(1988$, p. 19) explains that vowel harmony affects just the vowels of the affixes, meaning, the vowels in the affixes copy either the tongue root position or the tongue root and lip positions. Additionally, "that ATR-Harmony is the more basic process of the two whilst backness is only secondary and usually superimposed on the former when it occurs" This statement indicates that lip position assimilation occurs after the initial ATR harmony has occurred.

According to Akanlig-Pare (1994, p. 19), the rounded harmony depends on the advanced tongue root harmony. RH only depends on palatal and advanced tongue root harmony or left-right advanced harmony in Buli. Abakah (2003), then clarified that in a lot of cases, the labial harmony occurs with another type of harmony but it must be understood that in Akan the labial harmony co-occurs with dialect-specific restrictions in certain parts of the grammar". In this study, we concurred that the $\mathrm{RH}$ does not cut across the Mfantse dialect of Akan as many studies have shown but it is subdialect-specific or even subsub-dialect specific.

\section{Literature Review}

Mfantse, a dialect of Akan has received a great deal of phonological attention. A closer look at Mfantse shows that there are some differences including phonological, in the subdialects of Mfantse. Abakah (1978) undertook a phonological study on Iguae (Fetu) Fante and Nkusukum (Borbor) Mfantse. It is established in this research that these two subgroups have the same sounds i.e. vowels and consonants, however, their main differences lie in their tonal patterns, syntax, semantics and phonological processes. In each of these processes, the discussion centered on what exists in each subdialect, bringing out the differences. In another study, Abakah (2003) embraces RH as a major phonological phenomenon in Mfantse and proved

\footnotetext{
K C AL-KINDI CENTER $\mathbf{R}$ D FOR RESEARCH AND $\mathbf{R}$ D DEVELOPMENT Your gateway to world-class research
}

Published by Al-KindiCenter for Research and Development. Copyright (c) the author(s). This is an open access article under CC BY license (https://creativecommons.org/licenses/by/4.0/) 
it accordingly. Dolphyne (1988, p. 19), concurred and discussed RH as a phonological process in Mfantse. The study stated that, "All these examples of vowel harmony involve partial assimilation of the affixes, in order words the vowels in the affixes take on one feature - tongue root position - or two features - tongue root and lip positions." furthermore, RH is an additional harmony and therefore cannot occur alone. This is the more reason why other phonological processes are discussed in this paper in order to give a lead to the main focus of $\mathrm{RH}$.

Bota (2002) discussed three aspects of Bono phonology, sounds, phonological processes and tonal patterns. The work mentioned the differences in the major subdialects and also agrees that rounding harmony is evident in Akan. Andoh- Kumi (1971) and Yankah (1973) also looked at some differences between the Akan dialects and Agona which a variety of Mfantse. All the works mentioned above established differences even though all the dialects dealt with are Akan.

There are many categorizations of Mfantse depending on many factors but in this paper, we divide Mfantse into two main groups, coastal and inland Mfantse. Speakers of Borbor Mfantse are found at the South Eastern coast of Ghana designated Mfantseman District. However, some of Borbor speaking towns are found in the Abora-Asebu-Kwamankese District in the Central Region. Some major towns in Mfantseman are Mankessim, Saltpond, Egyaa. Edwumako is the name of both the people and the Mfantse subdialect spoken the northern half of the Central Region, i.e. Edwumako-Enyan-Esiam District. Some of its major towns are, Edwumako, Enyan Denkyira and Kokoben. The current study focused on Edwumako and Borbor subdialects of Mfantse. Investigations have confirmed Holmes' (2001, p. 195) statement that, "within a monolingual community the superficial impression may be that everyone speaks the same. (In a small town it often seems that everyone speaks the same language.) But a little thought will soon identify areas of variation..."

By this investigation, we outlined the sounds of Mfantse and show the differences that exist between them. We have also discussed some phonological processes and shown the differences and narrowed down to the rounding harmony types in the two subdialects of Mfantse.

\section{Autosegmental Phonology}

Autosegmental Phonology introduced by J.A. Goldsmith in 1976 and 1990 as an improvement on Generative Phonology. Goldsmith built on earlier works by Bernard Bloch (1948), J. R. Firth in (1948), Charles Hockett (1955) by modifying and applying the theory to some Bantu languages and Yoruba spoken in Nigeria. Goldsmith used the theory to account for tones and vowel harmony. The central idea of autosegmental phonology is that a segment, which is the abstract representation of sound, can be separated into sounds and then accounted for under phonological operations of deletion or the spreading. Suprasegments such as tone and nasality as well as harmony systems can be accounted for under such operations. In this framework, phonological representations are made up of more than one linear sequence of segments. A linear sequence constitutes a separate parallel tier with each tier representing a segment known as autosegment. The tiers are joined by association lines between the segments. The effect of restructuring results in the addition and deletion of association lines. Autosegmental analysis is useful because it can be used to analyse and account for both segments and suprasegments as in this study. Many studies including van de Weijer (2006), Bota (2002) and Akanlig-pare and Asante (2016) have proved vowel harmony in Lomongo (a Niger-Congo language spoken in the Democratic Republic of Congo), Bono and Nkami respectively.

\section{Methodology}

\section{Research sites and elicitation}

Three towns were selected in each of the Districts, i.e. Edwumako and Mfantseman. These towns were carefully selected such that the towns do not directly follow each other geographically. This was done in order to get the exact difference/s if any. We believe that three continuous towns may have little differences hence the choice of selection. Kokoben, Babinso, and Onwane were chosen in the Edwumako District while Anomabo, Mankessim and Akobima were selected in the Mfantseman district. Conditions for the selection of informants were 20 years and above and these people must have spent not less than ten years continuous in their communities. This was to ensure that this category of people have minimal linguistic boundary influence. Fifteen people were selected in each town. An English wordlist consisting of 400 words was showed to the participants to mention the Mfantse equivalents. This helped those who could not read. Spontaneous recordings were done on conversations at the market, a church forum, a proverb competition session, two story-telling sessions and some casual conversations. Some elders in the various communities were consulted to confirm the data to avoid biases.

\section{Discussion and findings: The Mfantse vowels}

The Mfantse vowels are not different from that of Akan. Mfantse has seven vowels in the orthography (phonemic) and 10 in phonetic transcription. These are; a, e, $\varepsilon, \mathrm{i}, \mathrm{o}, \mathrm{J}, \mathrm{u}$ and $\mathrm{a}, æ, \mathrm{l}, \mathrm{e}, \varepsilon, \mathrm{i}, \mathrm{u}, \mathrm{O}, \mathrm{J}$, u respectively. 
5.1 Mfantse Vowel Distribution

Both Abaka $(1978$, p. 13) and Dolphyne $(1988$, p. 2) have done extensive studies on Mfantse vowels and their position is that $/ æ /$ is in Mfantse but is always found at word final position. This was confirmed when most of the informants from Mankessim and Akobima pronounced their words in such manner. There was a mixture of pronunciations in Anomabo. Some pronounced /a/ in the word final position as /æ/ and others pronounced it /a/ with /æ/ occurring only at word final position. This is true of Borbor but not of Edwumako. What pertains in Edwumako is that instead of the central vowel /æ/, the low vowel /a/ is used. And this is similar to what happens in the rest of the Akan dialects such as Akuapem, Agona, Akyem and Asante. During elicitation in the Edwumako area, we found out that most of them used /a/. Those who pronounced it /æ/ were usually people who had lived along the coast or lived among Borbor speakers before or had formal education. Their speeches were interspersed with other Borbor sounds as well. The following are examples illustrate it.

Borbor

1. a. [bìsæ̇]

b. [sùæ̇]

c. [sìkǽ]

d. [pùsæ̀]

e. [kùræ̀]

f. [hùtæ̀]

\section{Edwumako}

[bìsà]

[sua]

[sika]

[pusa]

[kura]

[huta]
The rest of Akan

[bìsà]

[sua]

[sika]

[pusa]

[kuta]

[huta]

\section{English Gloss}

ask

to be small

money

boiled yam with stew for sale

to hold

to fan/blow air

It is known in Mfantse that /æ/ cannot be at word initial position but that is the case in Edwumako. Whenever Edwumako places the unadvanced central vowel /æ/ at word initial position, Borbor uses the advanced mid vowel /e/. This is what exists in the Twi dialects such as Asante Twi, Akyem and Akuapem Twi, indicating the influence these dialects have had on Edwumako which shares a border with them. Examples in two in the two names of towns in the Edwumako area and other words to illustrate the vowels /e/ and /æ/.
2. Borbor
Edwumako
a. [ènyắń]
[æ̀nyấń]
b. [èdwứmắkú]
[æ̇dwyứmắkú]
c. [èsíàm]
[æ̀siàm]
d. [èkúḿpùànó]
[æ̀kúmpùànó]
e. [èdzìbàń]
[æ̀dibàń]
[æ̀gúá]
f. [ègúá]

Rest of Akan

Phonemic

[æ̀nyã́ń]

Enyan

[æ̇dwyứmắkú]

Ajumako

[æ̇siàm]

Essiam

[æ̀kúḿnùànó]

[æ̀dùàné]

[æ̇dwá ]

\section{Ekumpoano \\ edziban/adiban/aduane \\ chair/seat}

From the above examples in two it is clear that where Borbor starts a word with the advanced mid vowel /e/, Edwumako uses the advanced central vowel. It is worth noting here that this does not apply to every word. There are words that are spelt the same way, beginning with the advanced mid vowel in both Edwumako and Borbor. Interestingly, they are the same in the rest in the Twi dialects. Consider the following example,

\section{Borbor/Edwumako}

3.
a. $\quad$ étú(ŕ)/ètú
b. isíw/èsíw
c. ikúŕr/èkúŕ
d. idzî́ń/èdî́ń
e. ìbún'èbứn

\section{English Gloss}

gun

an anthill

sore

name

valley

\section{Rest of Akan}

ètúó

èsié

èkúró

èdî́n

èbứnû́ 


\subsection{Nasalized Vowels}

It is well known in Fante and general Akan phonology that nasalized vowels acquire their nasality from adjacent nasal sounds. The two Mfantse oral vowels that can be nasalized are $/ \varepsilon, \jmath /$ therefore when $/ \varepsilon /$ and $/ \supset /$ are followed by /m/ and $/ \mathrm{n} /$ they become nasalized. Dolphyne (1988, p. 4) gave the following examples showing in 4.

4. $/ \tilde{\varepsilon} / \quad$ / $/$
a. fह̃́m
tวิ́n
b. bṍn
kốń

Investigations proved that when the rounded, unrounded unadvanced mid vowels / $\tilde{\varepsilon}, \tilde{\jmath} /$ precede /n/ they are nasalized in both Edwumako and Borbor, on the other hand when they precede $/ \mathrm{m} /$ they are not nasalized in Edwumako. The following are examples of $/ \tilde{\varepsilon}, \tilde{\jmath} /$ followed by $/ \mathrm{n} /$.

5.
a. sर̃́ń
b. bẽǹ
c. h h
e. sวั̀n
f. dṍn
g. tว̃́n

Edwumako

sर̃́ń

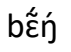

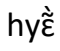

sวั்่̀

dว̃์

tวิ่์
English Gloss

to hang

to get closer to smb./sth.

to enter

to strain sth.

to make wet/soak

to sell

The examples below in six occur in Edwumako alone, likewise, pertain in other Akan dialects such as Akyem, Asante and Akuapem.

$\begin{array}{lll}\text { 6. } & \text { Edwumako } & \text { English Gloss } \\ \text { h. } & \text { féḿ } & \text { to borrow } \\ \text { i. } & \text { j̀kóḿ } & \text { hunger } \\ \text { j. } & \text { dóḿ } & \text { crowd } \\ \text { k. } & \text { sóḿ } & \text { to isolate oneself } \\ \text { I. } & \text { hyz̀m̀̀m } & \text { shiny/bright }\end{array}$

\section{Vowel Height in Borbor and Edwumako pronouns}

In Mfantse, as well as in all the Akan dialects the vowels /,$\varepsilon /$ are used as pronouns, specifically the third person singular pronoun. They represent the full forms "ono" for both animate and inanimate entities. These can be seen in the examples; गkJ, sba, odzi, otse, esui, etc. Aside these, Mfantse alone uses a vowel to represent the second person singular pronoun "э/wo". The difference in the realizations of this vowel in Edwumako and Borbor is rooted in height. Borbor realizes it as the front high vowels /i, l/ and front mid vowels /e, $\varepsilon /$ in Edwumako. The examples below in seven show the vowel in the environment of both advanced and unadvanced vowels.

\section{Borbor}

7. a. [ibókó]

b. [íkyì̀ náḿ]

c. [ítùkwấń]

d. [ítıwyà]

\section{Edwumako}

[غ̇bókó]

[غ̇ț̣iẁ nã́ḿ]

[ètùkwã́ń]

[èţ́wyà]

\section{English Gloss}

You will go

You fry fish/meat

You travel

You cut 
A few Borbor speakers, sometimes interchanged the high front vowel /// with the mid front vowel $/ \varepsilon /$ and the high advanced front vowel /i/ with the mid advanced front vowel /e/ as the case may be. This is not the case in Edwumako, hardly did any one use the vowels $/ \mathrm{i}, \mathrm{l} /$.

\section{Mfantse Consonants}

Mfantse has 18 consonants in the orthography and 34 in phonetic transcription. This was confirmed by Dolphyne (1988, p. 29) and Osam (2004, p. 6).

7.1 Differences in word final consonants

Consonants that are found at word final positions in Mfantse as well as in Akan are nasals. The nasals found are bilabial nasal $/ \mathrm{m} /$ and the alveolar nasal $/ \mathrm{n} /$ and also, the semi vowel $/ \mathrm{w} /$ and the trill $/ \mathrm{r} /$. Most phonological studies claim that the velar nasal $/ \mathrm{y} /$ ends words in Akuapem only. We posit here that Edwumako also ends words with the velar nasal, therefore, where Borbor ends with the alveolar nasal /n/ Edwumako uses the velar nasal $/ \mathrm{l} /$. In the examples in eight below, it is shown that Edwumako uses the velar nasal $/ \mathrm{y} /$ to end words just like it occurs in Akuapem while Borbor uses $/ \mathrm{n} /$.

\begin{tabular}{|c|c|c|c|}
\hline Borbor & Edwumako & Akuapem & English Gloss \\
\hline /nằǹ/ & /nằǹ/ & /nã̀ǹ/ & to melt \\
\hline /dầǹ/ & /dằǹ/ & /dằǹ/ & to turn \\
\hline /pấń/ & /pấń/ & /pấń/ & to pluck \\
\hline /ذ̀mắń/ & /j̀mấń/ & /ذ̀mấń/ & country \\
\hline 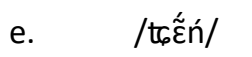 & /țع̃́ń/ & /țદ̌́ń/ & to be more than/exceed \\
\hline
\end{tabular}

It is important to note here that the examples in eight are realized in speech or in the spoken language only. A further testing on all the ten vowels proved that this happens with only front vowels that are followed by the alveolar nasal in Edwumako. Tables one and two at the end of the write-up indicate that in Borbor, it happens even in the environment of both front and back vowels.

9.

Borbor Edwumako
a. /pứń/
b. /sว̃̀n/
c. /tốń/
d. /(う̀)pứń/
e. /bṍń/

\section{Asante/Akyem English Gloss}

\begin{tabular}{|c|c|}
\hline 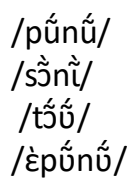 & $\begin{array}{l}\text { to inhale } \\
\text { to strain } \\
\text { to sell } \\
\text { table }\end{array}$ \\
\hline /bכ̃̃̂́ / & smell \\
\hline
\end{tabular}

Further testing led to a different result with back rounded vowels. As exemplified in example nine above, when the final alveolar nasal is preceded by a back vowel in a word, the nasal is replaced by a nasalized /u/or / $/$ which are both high back and rounded vowels. It is either the advanced high back vowel / $\mathrm{u}$ / in the environment of advanced back vowels or the unadvanced back vowel / $\mathrm{v} /$ occurring with unadvanced back vowels. This also pertains in Akyem and Asante as seen. Akuapem however, uses the same velar nasal with rounded vowels.

\section{Rounding Harmony (Labialised harmony)}

The phonemic environment can result in labialized harmony. The vowels are the ones that usually undergo the harmonization process. In this section, we look at pronoun and tense prefixes, since some of the Mfantse pronouns are attached to verbs as one unit. The vowels in the first and third person pronouns depend on the advanced and the unadvanced harmony and then the labialized harmony. This is demonstrated on table three at the end of the paper.

The table on pronoun prefixes is divided into two major parts. The first division on the left contains the types of pronouns that are used as prefixes for verbs. The second part on the right also demonstrates how these two prefixes depend on advanced and unadvanced vowels for modification. As the vowel in any of the verbs occur with the pronouns, they are harmonized with the pronouns. See the examples on possessive sentences below. 
10.

Possessive Pronoun. $1^{\text {st }}$ person

a. mi kyew

b. mi sika

d. mu pun

e. mubuw
Possessive Pronoun $3^{\text {rd }}$ person

ni t6ew

ni sika

nu pun

nu buw

Below is the autosegmental analysis of example 10b) above

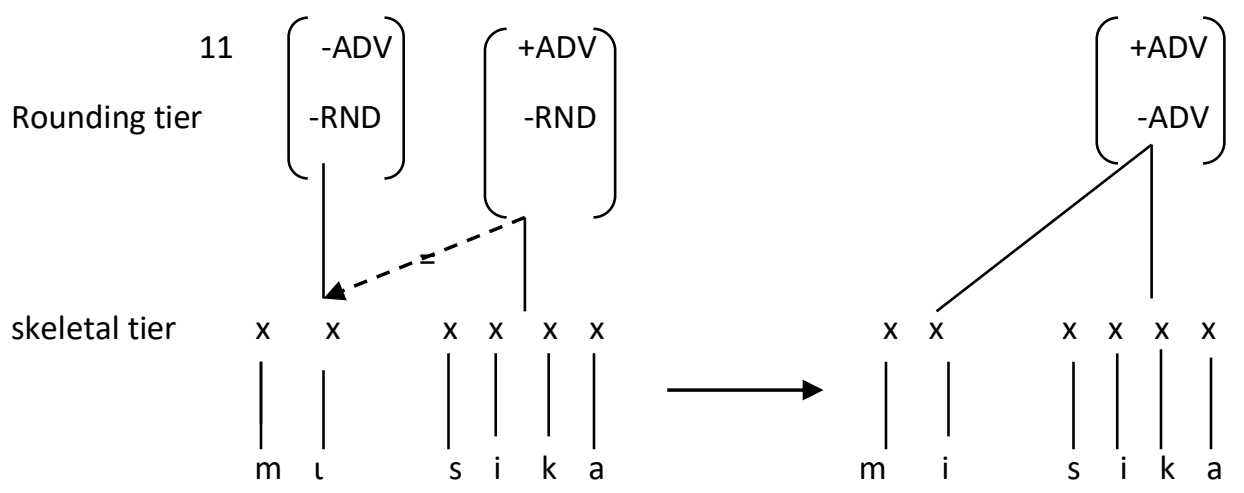

'My money'

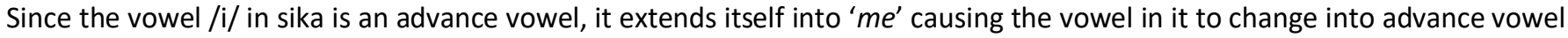
/i/.

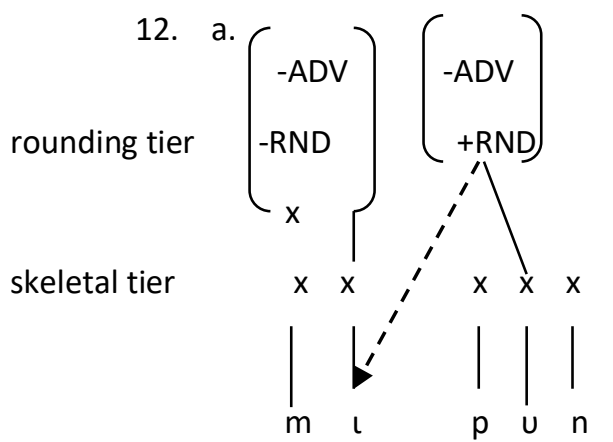

b.

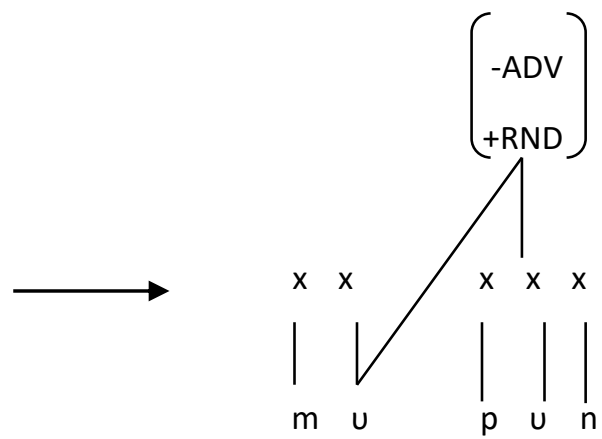

'My table'

In example 12 above, the vowels in both words of the sentence are advanced. Therefore, the major harmony that occurs is labialization which involves $/ \mathrm{u} /$ and labial palatalization with /l/. The result is that /l/ copies $/ \mathrm{u} /$ in pun to become /mu/. It is evident that this also occurs in Borbor Mfantse. Clearly, no changes occur in $/ \mathrm{ml} / \mathrm{and} / \mathrm{nl} /$ which is the first one, because, this is how these pronouns are presented in the language. They always occur with the advanced and the unadvanced vowel in a word as demonstrated in the table 4.

Table four has two main divisions. The tenses are on the left, and their four different prefixes on the right. The prefixes are categorized into four per the advanced and the unadvanced rule of Borbor. Example 13 occurs with the tense used for the third person singular possessive pronoun.

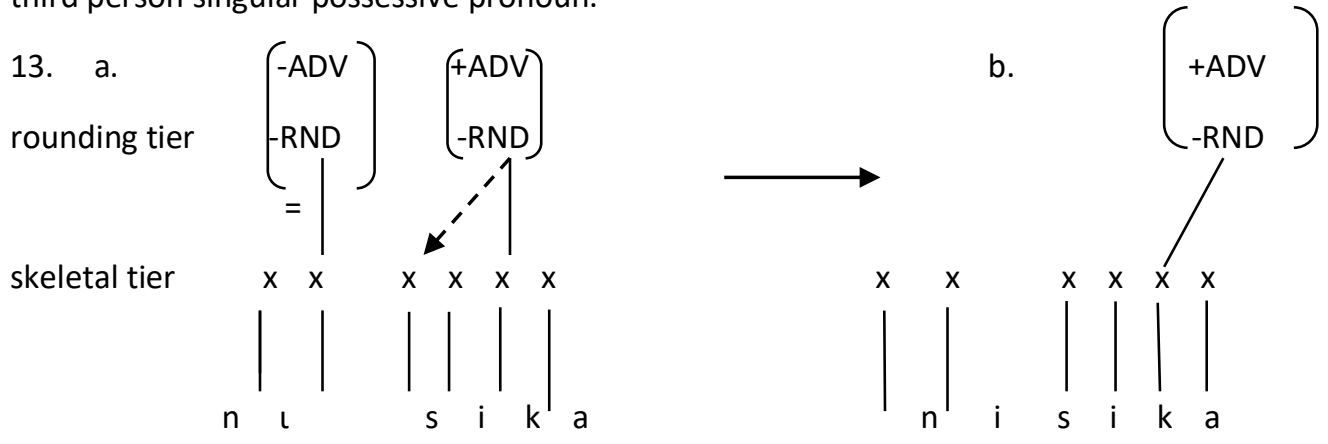


The vowel /i/ in sika is an advanced vowel, it assimilates the /e/ in ' $n e$ ' causing the into /i/ which is an advanced vowel.

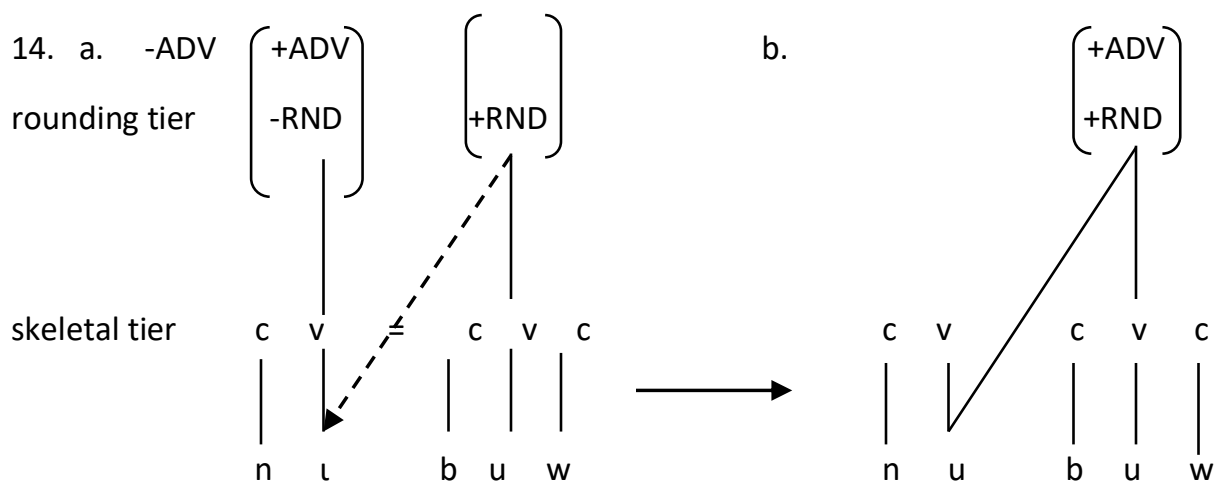

Two different harmony types occur in example 14 . The first is the advanced tongue root which changes $/ \mathrm{l} / \mathrm{to} / \mathrm{i} /$. Then, the labialized / $\mathrm{u}$ / in 'buw' extends itself into /i/ which changes the / $\mathrm{u} /$ as it has been illustrated in the example 14.

\section{Labialization harmony in Edwumako}

As mentioned earlier, the particular prefix which is placed at the initial of a word in both Borbor and Edwumako depends on the vowel in the word. This is illustrated on table five.

One major thing that occurs on table five is that, labialized harmony does not occur in $1^{\text {st }}$ person possessive pronoun (me) and $3^{\text {rd }}$ person possessive pronoun (ne) in Edwmako Mfantse. A similar instance occurs in Edwumako in possessive pronouns and also occurs in all the Akan dialects, nonetheless, labialization does not exist in the other Akan dialects. Example 15 shows some of the examples obtained from the Edwumako data.

\section{Mfantse}

15.
a. 'Misaw mi nsu no a ...'
b. 'Mt kospoo no ...'
d. 'Ni kun fi edwuma a ...'
e. 'Nt sofue ...'

\section{English}

\begin{abstract}
'When I draw my water ...'
\end{abstract}
'My cup ...'

'When her husband returns from work ...'

'His/her pastor ...'

(Edwumako 6:17 pm)

There is a harmony that occurs with the progressive marker re. It is evident that the progressive marker ' $r$ ' used in all Akan dialects is not used in speech in the Edwumako subdialect. In Edwumako it is derived by lengthening the final vowel in the word which comes before the verb. Below are some of the examples from the data, the examples were part of the spontaneous conversations. They are the same in spoken Asante and Akyem.

15.
a. Kwamee dow mfikyir ho
b. $\quad$ Oopue gua do

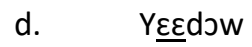
e. $\quad$ Miididi

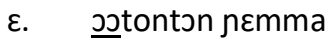

\section{Written language}

Kwame rudow

orupue gua do

Yerudow

Miridzidzi

Jrutonton ndzemba

\section{English Gloss}

Kwame is weeding

He is going out

We are weeding

I am eating

$\mathrm{He} /$ she is selling things

(Edwumako 6:16 pm)

Table six shows the future egressive prefix 'ko/ke occur with vowels based on their rounded or unrounded nature. /ko/ ocurrs with rounded vowels while / $k \varepsilon /$ occurs with unrounded vowels. Though the progressive marker ' $r$ ' is not used in Edwumako, the lengthened vowel which is added to it agrees with the vowel in the pronoun. As illustrated in example 16 below, when 
the word that precedes the verb is even a noun, it copies the advanced vowel. The example below is the Autosegmental representation.

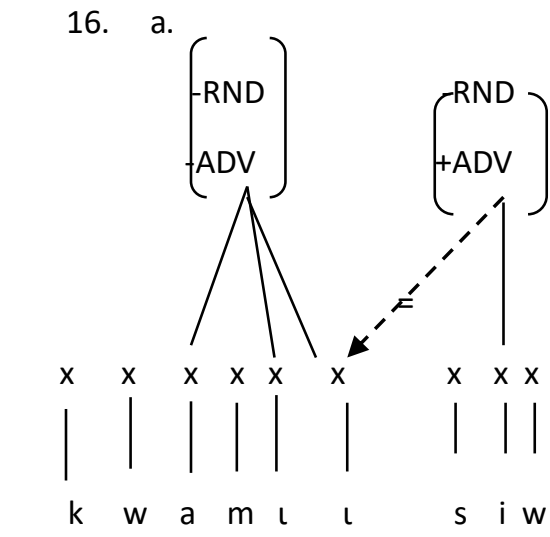

d.

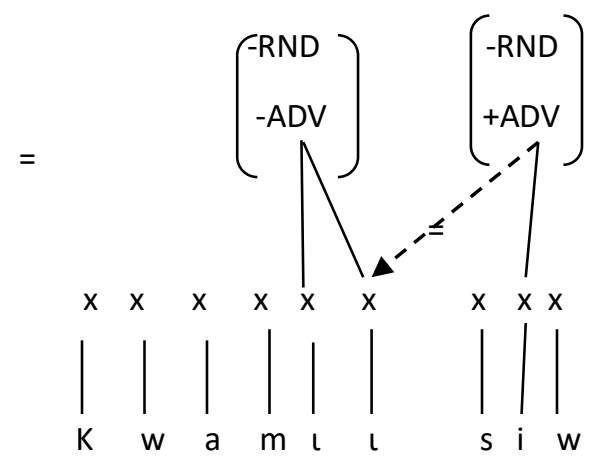

b.

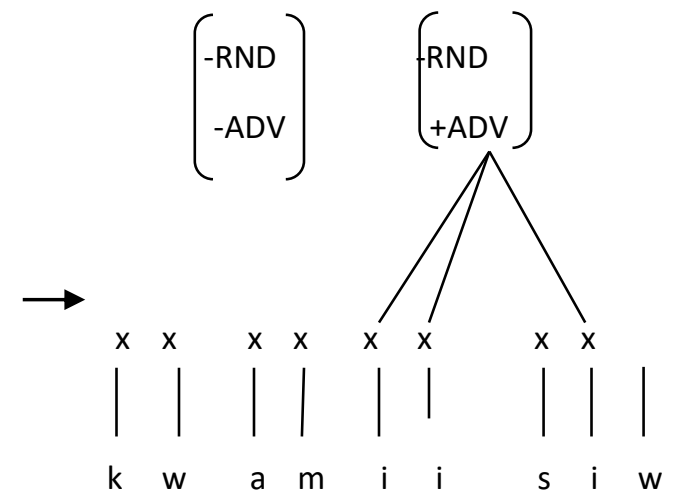

e

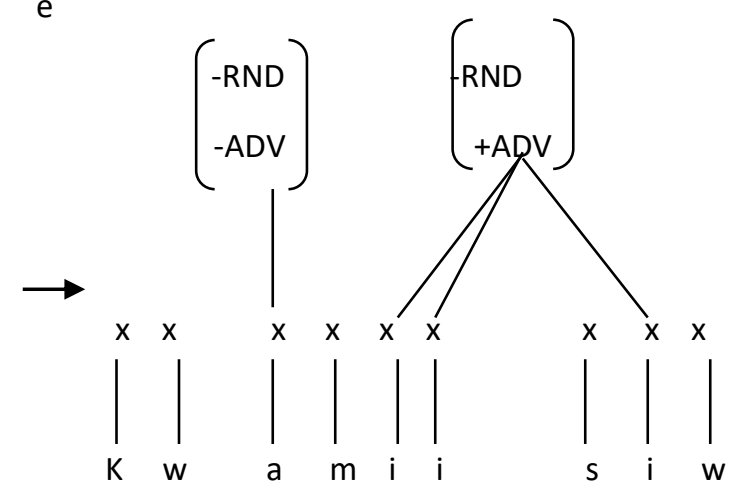

Since the vowel in the verb is advanced, it spreads leftwards or regressively to assimilate the vowel in the noun which changes to an advanced vowel. In autosegemental analysis, association lines do not cross, so this has caused the advanced nature to assimilate the final /i/ before it affects the second /i/. Below are other examples from Edwumako.

\section{Speech}

a. Adəwu kodu

b. Adıpamu bre ası

c. Kurowii gu
Writing

Adəw rokว do

Adzıpam rıbre adzı

Kurow rugu

\section{English}

Farming is ongoing

Sewing is becoming unpopular

The town is being deserted

(Edwumako 7:16 pm)

From the examples in 17 a to $c$ above, the lengthened vowel that is attached to the pronoun depends on the progressive tense marker 're' to achieve its + or -round status. The roundness or unroundness has nothing to do with the vowels in the verb or pronouns.

\section{Summary of Findings}

The study has proved that even though Mfantse is one dialect of Akan with the same consonant and vowel inventory there are differences in their places of occurrences. The study has shown that the central unadvanced vowel /æ/ occurs at only word final in Borbor but it could be both word initial and word final in Edwumako. Also, the alveolar nasal $/ \mathrm{n} /$ is replaced by the velar nasal $/ \mathrm{h} /$ in Edwumako. The central unadvanced vowel $(\varepsilon)$ that is nasalised when it occurs before nasals is not nasalised in Edwumako Edwumako, meanwhile the final alveolar nasal at word final is replaced by a nasalised vowel. There is also variation in vowel such that where Borbor uses the advanced mid vowel /i/ at word initial but Edwumako uses the advanced central vowel /e/ instead. In terms of rounding harmony which usually affect. Vowel harmony is not the same in these two dialects. In Borbor, the rounding feature spreads from the possesum to the vowel in the first and third possessive pronouns. The autosegmental analysis done proved the direction of the spread and the final restructuring. 


\section{Conclusion}

There has been a longstanding knowledge by Akan scholars that vowel harmony exists in the various dialects of Akan including Mfantse. There has been no evidence to discredit such view because most of the examples used are from written language. Speakers of Mfantse though have always distinguished themselves based on their auditory perceptions. In view of this, there was the need to delve into the spoken Mfantse dialects to see what Mfantse speakers base their differences on. The spontaneous speeches data used for this study have helped to uncover differences in the Mfantse harmony. There were instances where both Edwumako and Borbor, the standard variety displayed the same harmony types. There were also instances where only Borbor displayed such tendencies while some instances showed only Edwumako having a certain harmony type. One thing that stands out is that, Edwumako rather shares some harmony types with the Twi dialects, Asante and Akuapem. The harmony that occurred in both are usually accompanied by phonological processes such as labialization and palatalization. This study has proved that vowel harmony does not cut across in Mfantse but peculiar, based on the dialect and its spatial relationship with the Twi dialects. We recommend that subsequent studies look at other Mfantse other subdialects to establish the harmony differences realised by speech and not the written language which is the standard for all.

\section{References}

[1] Abakah, E. N. (1978). Dialect Differences Between Iguae Fante and Borbor (Nkusukum)(Nkusukum) Fante. Long Essay. University of Ghana.

[2] Abakah E. N. (2003). The Segmental and Tone Melodies of Akan. Nowegian University of Science and Technology.

[3] Abakah, (2012). Some Assimilatory Processes in Akan. Journal of West African Languages, 39(2).

[4] Andoh-Kumi, K. (1971). A Pilot Dialect Geography of Agona Long Essay. University of Ghana.

[5] Akanlig-Pare, G. (1994) Aspects of Buli Phonology. MPhil thesis. University of Ghana.

[6] Akanlig-Pare, G., \& Asante, K.R., (2016). Vowel Harmony in Nkami. Journal of West African Languages, 43(1).

[7] Bota, G. (2002). Aspects of Bono Phonology. An Autosegmental Analysis. MPhil Thesis. University of Ghana.

[8] Bloch, B, (1948). A set of postulates for phonemic analysis. Language 24.

[9] Casali, R. F. (2016). Some inventory-related asymmetries in patterning of tongue root harmony systems. Studies in African Linguistics, $45(1 \& 21$.

[10] Clements, G. N. (1976). Vowel harmony in nonlinear generative phonology: an autosegmental model. Indiana University Linguistics Club.

[11] Districts in Ghana. http://www.ghanadistricts.com

[12] Dolphyne, F. A. (1979). The Brong (Bono) Dialect of Akan. In K. A. Brong Kyempem Chapter VII. Accra, Afram Publications.

[13] Dolphyne F.A. (1988). The Akan (Twi-Fante) Language. Its Sound Systems and Tonal Structure. Accra: Ghana Universities Press.

[14] Fanti. http://www.ghanaweb.com/GhanaHomePage/tribes/fanti.php

[15] Firth, J.R. (1948). Sounds and Prosodies" Transactions of the Philological Society, pp 127-52.

[16] Goldsmith J. A. Autosegmental Phonology. (1979)a. https://www.researchgate.net/publication/37599756

[17] Goldsmith, J. (1990)b. Autosegmental and metrical phonology. Basil Blackwell.

[18] Hockett, C. (1955)c. A manual of phonology. Indiana University Publications in Anthropology and Linguistics 11.

[19] Holmes, J. (2001). An Introduction to Sociolinguistics. Second edition. Pearson EducationLimited.

[20] Moller, M. (2016). Vowel Harmony in Bale: A study of ATR harmony in a Surmic languageof Ethiopia. http://su.divaportal.org/smash/record.jsf?pid=diva2\%3A233078\&dswid=9744

[21] Morton, D. (2012). [ATR] Harmony in an Eleven Vowel Language: The Case of Anii. In Selected Proceedings of the 42nd Annual Conference on African Linguistics, ed. Michael R. Marlo et al., 70-78. Somerville, MA: Cascadilla Proceedings Project.

[22] Obeng, S.G. (1999) Conversational Strategies in Akan: Prosodic Features and Discourse Categories. Cologne: Rüdiger Koppe Verlag.

[23] Osam, E.K. (2004). The Trondheim Lectures. An Introduction to the Structure of Akan: Its Verbal and Multiverbal Systems. Combert Impressions, Accra.

[24] Sharon R. (2016). ATR Vowel Harmony: new patterns and diagnostics. https://www.core.ac.uk/download/pdf/230169795.pdf 
Tables

Table one. The final consonant / $\mathbf{n} /$ in Borbor

\begin{tabular}{|l|l|l|l|l|l|l|l|l|}
\hline $\begin{array}{l}\text { Mfantse } \\
\text { vowels }\end{array}$ & a & e & l & $\varepsilon$ & i & o & o & u \\
\hline $\begin{array}{l}\text { final } \\
\text { consonants }\end{array}$ & páń & péñ & sín & péń & pín & póń & póń & púń \\
\hline $\begin{array}{l}\text { English } \\
\text { gloss }\end{array}$ & pluck & $\begin{array}{l}\text { sound of } \\
\text { breaking }\end{array}$ & $\begin{array}{l}\text { pass } \\
\text { by }\end{array}$ & pen & $\begin{array}{l}\text { push } \\
\text { over }\end{array}$ & redeem & close & inhale \\
\hline
\end{tabular}

Table two. Final consonant /n/ in Edwumako

\begin{tabular}{|l|l|l|l|l|l|l|l|l|}
\hline $\begin{array}{l}\text { Mfantse } \\
\text { vowels }\end{array}$ & a & e & l & $\varepsilon$ & i & o & ว & u \\
\hline $\begin{array}{l}\text { final } \\
\text { consonatnts }\end{array}$ & pan & pen & sın & tipen & pin & - & - & - \\
\hline $\begin{array}{l}\text { English } \\
\text { gloss }\end{array}$ & pluck & $\begin{array}{l}\text { sound of } \\
\text { breaking }\end{array}$ & $\begin{array}{l}\text { pass } \\
\text { by }\end{array}$ & agemate & $\begin{array}{l}\text { push } \\
\text { over }\end{array}$ & & & \\
\hline
\end{tabular}

Table three: Pronoun prefixes

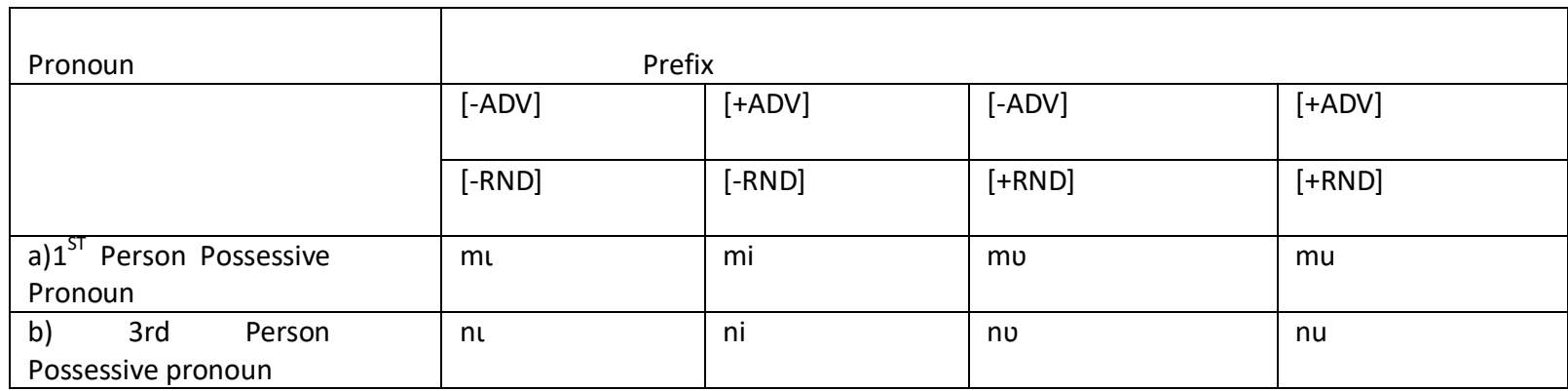

four. $\mathbf{R H}$ in tense prefixes in Borbor

\begin{tabular}{|l|l|l|l|l|}
\hline & \multicolumn{4}{|c|}{ Prefix } \\
\hline & - RND & + ADV & -ADV & +ADV \\
tenses & -RND & -RND & +RND \\
\hline 1. progressive & rl & ri & ru & ru \\
\hline 2. egressive & ke & ke & kJ & ko \\
\hline 3. ingressive & be & be & bo & bo \\
\hline & be & be & bo & bo \\
\hline
\end{tabular}

Table five. Harmony in Edwumako Pronouns

\begin{tabular}{|c|c|c|c|c|}
\hline \multirow[t]{2}{*}{ Pronouns } & \multicolumn{4}{|c|}{ Prefix } \\
\hline & $\begin{array}{l}-A D V \\
\text {-RND }\end{array}$ & $\begin{array}{l}+A D V \\
\text {-RND }\end{array}$ & $\begin{array}{l}\text {-ADV } \\
\text { +RND }\end{array}$ & $\begin{array}{l}+A D V \\
+A D V\end{array}$ \\
\hline $\begin{array}{l}1^{\text {ST }} \quad \text { person } \\
\text { possessive pronoun }\end{array}$ & $\mathrm{ml}$ & $\mathrm{mi}$ & - & - \\
\hline $\begin{array}{l}\text { 3rd Person Possessive } \\
\text { Pronoun }\end{array}$ & $\mathrm{nt}$ & ni & - & - \\
\hline
\end{tabular}


Table six. $\mathrm{RH}$ in tense prefixes in Edwumako

\begin{tabular}{|c|c|c|c|c|}
\hline & \multicolumn{4}{|c|}{$\underline{\text { Prefixes }}$} \\
\hline & $\begin{array}{l}-A D V \\
-R N D\end{array}$ & $\begin{array}{l}\text { ADV } \\
\text {-RND }\end{array}$ & $\begin{array}{l}\text {-ADV } \\
+ \text { RND }\end{array}$ & $\begin{array}{l}+\mathrm{ADV} \\
+\mathrm{ADV}\end{array}$ \\
\hline 1. Progressive & - & - & - & . \\
\hline 2. future & $b \varepsilon$ & be & bo & bo \\
\hline 3. egressive future & - & - & ko & ko \\
\hline 4. ingressive future & $\mathrm{b} \varepsilon$ & be & bo & bo \\
\hline
\end{tabular}

